\title{
DR-66
}

\section{THE EFFECTS OF FEED ADDITIVES BASED ON THE WASTES OF POULTRY PROCESSING ON THE PRODUCTIVE PERFORMANCE AND MEAT QUALITY IN BROILER CHICKS}

\author{
V.S. Lukashenko ${ }^{1, a)}$, I. P. Saleeva ${ }^{1, b)}$, E.A. Ovseychik ${ }^{1, c)}$, E.V. Zhuravchuk ${ }^{1, d)}$ V.G. Volik ${ }^{2, e)}$ \\ and D.Yu. Ismailova ${ }^{2, f}$
}

\author{
${ }^{1}$ Federal Scientific Center "All-Russian Research and Technological Institute of Poultry” \\ of Russian Academy of Sciences, Ptitsegradskaya Str., 10, Sergiev Posad, \\ Moscow Province, 141311 Russia \\ ${ }^{2}$ All-Russian Research Institute of Poultry Processing - branch of the Federal Scientific Center \\ "All-Russian Research and Technological Institute of Poultry” of Russian Academy of Sciences, \\ Rzhavki, Solnechnogorsk1District, Moscow Province, 141552 Russia;
}

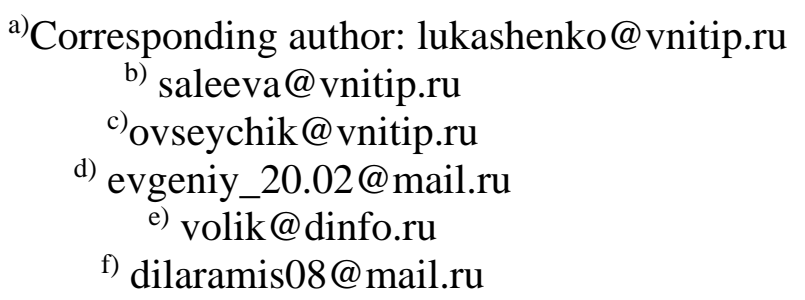

Due to the significant growth in poultry production, the volume of deep processing of poultry is increasing. When it is processed, a significant proportion of by-products (feathers, heads, feet, blood, etc.) are obtained. The wastes of the slaughter and primary processing of poultry could potentially be used as animal protein sources for broilers. Feed additives based on these wastes can solve the problem of their utilization and offer an opportunity to save on the more expensive animal protein sources. As it known, by-products are the most valuable source of animal protein. Of particular interest are the feather and meat and bone residue.There are several ways to obtain hydrolysates. One of them is important for enzymatic hydrolysis. Therefore, a promising technological method for processing secondary raw materials is its short-term high-temperature treatment followed by enzymatic hydrolysis. The combination of hightemperature processing and subsequent enzymatic hydrolysis allows you to obtain feed protein additives with the maximum preservation of available amino acids, intended later for the enrichment of feed rations, used in poultry farming. Special treatments are required to improve the digestibility of dietary keratin; these treatments should decompose its native structure and make it available for the proteolytic enzymes of gastrointestinal tract of broilers. E.g. the two-stage hydrolysis of feathers (short-term intense thermal treatment with subsequent enzymatic hydrolysis) was reported to protect up to $85 \%$ of the most valuable amino acids within the keratin. The evident advantages of this approach include energy saving, preservation of bioactive substances, and high resulting digestibility of protein, up to $92 \%$. Study the effects of feed additives based on the hydrolysates of feathers and collagen on the productive performance and meat quality in broiler chicks. The productive performance and meat quality were studied in broiler chicks fed diets supplemented with easily digestible animal derived protein additives produced by shortterm intense thermal treatment and enzymatic hydrolysis of keratin- and collagen-containing wastes of slaughter and processing of poultry. The trial was performed on 4 treatments of Ross-308 broilers (50 birds per treatment, from 1 to 38 days of age). Control treatment was fed diet with fishmeal as animal protein source; in treatments 2 and 3 the fishmeal was substituted by enzymatic hydrolysate of feathers (keratin-containing wastes) with and without probiotic preparation, respectively; in treatment 4 the fishmeal was substituted by a mixture of enzymatic hydrolysates of feathers and collagen-containing wastes with probiotic preparation. It was found that average live bodyweight at slaughter age was higher in all experimental treatments in compare to control. The best results were found in treatment 3: live bodyweight at 38 days of age was significantly higher by $8.6 \%(\mathrm{P}<0.001)$ while feed conversion ratio was lower by $6.7 \%$ in compare to control; this treatment also featured the best yields of carcass parts and meat quality. 